\title{
Revitalisasi moral kewarganegaraan dalam ungkapan Jawa sebagai sumber pembentukan civic culture dan politic culture
}

\author{
Yoga Ardian Feriandi \\ Universitas PGRI Madiun \\ yogaardianferiandi@unipma.ac.id
}

\begin{abstract}
This article aims to understand and multiply the moral values that exist in the expression of Java. Of the values excavated the hope can be a reference as the formation of civic culture and politic culture. The type of research used in this research is qualitative research, with descriptive-critical method, which in his explanation more emphasis on the power of data analysis on existing data sources. This study is based on library research. The object of the studies in the form of notes, transcripts, books, Journal of Research and so on which is linked to the study of Javanese culture, civic culture and politics culture. From the results of the discussion then known some phrases like aja dumeh, mendhem jero mikul dhuwur, jer basuki mawa bea. Having moral universal citizenship values so as to become a reference in order to form the civic culture which could further impact on politics culture as an effort to civil society in the Republic of Indonesia.
\end{abstract}

Keywords: civic culture; Java culture; politic culture

\section{Pendahuluan}

Dalam berdirinya suatu negara salah satu syarat wajibnya adalah adanya penduduk/warganegara, sehingga negara dan warganegara menjadi suatu subjek yang saling terkait secara terus menerus. Keterkaitan tersebut sering memunculkan berbagai permasalahan kewarganegaraan terkait hak dan kewajiban warganegara maupun negara. Persoalan kewarganegaraan tersebut adalah persoalan moral secara subjektif dan politik secara objektif. Secara subjektif setiap warganegara dinisbahkan menjadi pemilik atau pendukung keberadaan negara. Sedangkan kedudukan objektifnya, secara politik bahwa setiap warganegara juga adalah menjadi alat pencapaian tujuan atau kepentingan negara dengan segala kompleksitasnya. Maka dari itu dalam suatu negara diperlukan adanya aturan yang mengikat kuat selain hak-hak dasar sebagai warganegara, yakni berupa moral kewarganegaraan. Moral kewarganegaraan sendiri merupakan suatu pedoman/patokan kehidupan warganegara yang dapat membantu menilai suatu tindakan merupakan sesuatu yang salah atau benar.

Moral kewarganegaraan sebenarnya telah ada dan hidup dalam budaya masyarakat namun sayangnya tidak semua masyarakat mengetahuinya. Kecenderungan yang ada sekarang masyarakat lebih tertarik dalam mempelajari budaya serta mengali nilai-nilai moral yang berkembang di negara lain untuk di gunakan sebagai dasar untuk berperilaku serta dibanggakan sebagai menjadi suatu identitas yang dianggap terkini. Melalui derasnya informasi era globalisasi masyarakat terutama anak muda seakan terhegemoni dengan nilai-nilai asing yang ditemuinya, mereka membanggakan diri untuk berperilaku dan berbudaya yang mencerminkan identitas yang berasal bangsa lain. Padahal akan lebih baik bila kita sebagai warganegara Indonesia lebih menjunjung nilai moral dari budaya kita sendiri, yang terbukti sesuai dengan kepribadian bangsa kita. 
Tanpa mengecilkan peran komunitas kultural etnis lain pendukung kebhinekaan Nusantara dalam kesatuan Indonesia, budaya jawa menjadi salah satu budaya yang menarik untuk dikaji nilai-nilai moralnya. Misalnya saja terdapat ungkapan jawa ojo dumeh, yang dapat diartikan bahwa setiap orang tidak boleh sombong meski memiliki jabatan tinggi. Yang patut disayangkan adalah ungkapan-ungkapan / artikulasi yang memiliki nilai moral dari budaya jawa tersebut tidak lagi popular di kalangan masyarakat jawa, bahkan ada yang sudah tidak mengenalnya lagi (Rahyono, 2009, p. 85). Jika dikenal saja tidak maka niscaya nilai-nilai moral yang sebenarnya terkandung di dalamnya juga sudah tidak diimplementasikan lagi.

Selain dapat menjadi sumber moral kewarganegaraan budaya jawa juga dapat menjadi sumber bagi pembentukan budaya kewarganegaraan (civic culture). Civic culture sendiri merupakan budaya yang menopang kewarganegaraan yang berisikan seperangkat ide-ide yang dapat diwujudkan secara efektif dalam representasi kebudayaan untuk tujuan pembentukan identitas warganegara. Sedangkan politic culture merupakan pemikiran yang khas dan berpola tentang bagaimana kehidupan politik dan ekonomi yang seharusnya diselenggarakan (Winataputra, 2012, p. 57). Sehingga dari hal itu dapat kita pahami bahwa terdapat hubungan timbal balik antara civic culture dengan politic culture, dimana karakter atau identitas keindonesiaan yang ada dalam civic culture akan di bawa oleh para pelaku politik (eksekutif dan legislatif) untuk dicerminkan dalam berbagai perilakunya sebagai wakil rakyat dalam konteks pembangunan sosial, politik, ekonomi dan budaya.
Pengalian budaya Jawa yang dimaksud di sini bukan bermaksud untuk menonjolkan budaya dari suatu etnis tertentu, namun hanya bertujuan untuk membuktikan bahwa dalam budaya jawa terdapat nilai-nilai universal yang juga diterima secara menyeluruh oleh rakyat Indonesia, sehingga dapat menopang kehidupan kewarganegaraan untuk selanjutnya menjadi sarana pemersatu dari berbagai macam atribut yang ada. Sepatutnya budaya yang ada dan berkembang di Indonesia haruslah dapat dilestarikan dan diwujudkan secara efektif guna membentuk identitas warganegara. Untuk itu pada artikel ini akan berusaha untuk menggali nilai-nilai moral kewarganegaraan pada budaya jawa khususnya pada ungkapan-ungkapan jawa serta hubungannya untuk membentuk civic culture dan politic culture.

\section{Metode}

Jenis Penelitian yang digunakan dalam penelitian ini yakni penelitian kualitatif, dengan metode deskriptif-kritis, yang dalam penjelasannya lebih menekankan pada kekuatan analisis data pada sumber-sumber data yang ada. Sumber-sumber tersebut di peroleh dari berbagai buku dan tulisan-tulisan lainnya dengan mengandalkan teori-teori yang ada untuk diinterpretasikan secara jelas dan mendalam untuk menghasilkan tesis dan anti tesis (Abdurrahman \& Soerjono, 1999, p. 25). Studi ini mendasarkan kepada studi kepustakaan (library research). Objek penelitian ini berupa catatan, transkrip, buku, Jurnal Penelitian dan sebagainya yang mempunyai keterkaitan dengan kajian tentang budaya jawa, civic culture dan politic culture.

Teknik pengumpulan data dengan dokumentasi, mengidentifikasi wacana dari buku-buku, makalah atau artikel, majalah, jurnal, koran, web (internet), ataupun informasi lainnya yang berhubungan dengan 
judul penulisan untuk mencari hal-hal atau variabel yang berupa catatan, transkrip, buku, jurnal penelitian dan sebagainya yang mempunyai keterkaitan dengan kajian tentang budaya jawa, civic culture dan politic culture.

Dalam penelitian ini, setelah data terkumpul maka data tersebut dianalisis untuk mendapatkan konklusi, bentuk-bentuk dalam teknik analisis deskriptif.

\section{Hasil dan Pembahasan}

Moral berasal dari kata "mos" atau "mores" (jamak) dari Bahasa Latin yang berarti adat istiadat (Muchson AR, 2009, p. 17). Dalam Bahasa Yunani kata moral dikenal dengan kata "ethos" yang selanjutnya menurunkan istilah etika. Sependapat dengan pendapat tersebut. Bertens (2005, p. 6) menuliskan kata moral secara etimologis sama dengan kata etika. Menurutnya arti kata moral dapat dilihat sebagai nomina atau adjektiva. Sebagai nomina, kata moral sama dengan arti etika yang pertama, yaitu nilainilai dan norma-norma yang menjadi pegangan bagi seseorang atau suatu kelompok dalam mengatur tingkah lakunya. Sebagai adjektiva, kata moral sama artinya dengan etis.

Dalam berbagai aktivitasnya masyarakat jawa senantiasa memiliki prinsip atau pegangan yang berasal dari budayanya sendiri untuk digunakan sebagai pedoman dalam bertingkah laku. Prinsip tersebut tercermin dari berbagai ungkapan yang ada pada masyarakat jawa, seperti: aja dumeh, mendhem jero mikul dhuwur, jer basuki mawa beya.

Ungkapan dumeh merupakan suatu sikap seseorang yang mendorong untuk berbuat sewenang-wenangnya menurut kehendak sendiri, sehingga lupa diri, sedangkan kata aja jika diartikan dalam Bahasa Indonesia berarti jangan sehingga aja dumeh merupakan semboyan yang menekankan pada seseorang untuk tidak berlaku semena-mena meski memiliki kekuasaan (Besar, 2010; Bratawijaya, 1997; Rahyono, 2009). Rahyono (2009, p. 82) menjelaskan bahwa aja dumeh bukan hanya merupakan rangkaian dua kata yang hadir begitu saja, aja dumeh merupakan suatu proposisi yang menjadi salah satu butir ungkapan kebudayaan. Anggota masyarakat Jawa menghayati maknanya sebagai salah satu upaya sadar bahwa keserakahan dan keangkuhan manusia dapat mengakibatkan tatanan dunia menjadi rusak. Berikut beberapa contoh kalimat yang mengandung muatan ojo dumeh yakni dumeh kowe kuwasa trus biso 'ngidek-idek' sedulurmu sakepenake? (Mentang-mentang kamu berkuasa terus bisa 'menginjak-injak' saudaramu dengan seenaknya?). Dumeh kowe sugih trus biso sia-sia marang sedulurmu kang ora duwe? (Mentang-mentang kamu kaya terus bisa menyia-nyiakan saudaramu yang tidak berpunya?). Dumeh kowe pinter trus biso sakepenake nggunakake kapinteranmu kuwi kanggo 'minteri' wongwong sing ora ngerti apa-apa? (Mentangmentang kamu pandai terus bias menggunakan kepandaianmu itu untuk membodohi orang lain yang tidak mengerti apa-apa?). Dumeh kowe luwih ngerti trus biso 'petantang-petenteng' lan nganggep wong liya ora ana ajine opo-opo? (Mentangmentang kamu lebih mengerti terus bisa tolak pinggang setinggi dada dan mengganggap orang lain tidak ada harganya di depanmu?). Dumeh kowe luwih 'cedhak karo gusti' trus ngganggep wong liya murtad? (Mentangmentang kamu lebih dekat dengan Tuhan terus menganggap orang lain murtad?) (Besar, 2010, p. 662).

Tuturan aja dumeh diciptakan melalui proses pemikiran yang mendalam 
berdasarkan fakta yang ada di dunia nyata. Dengan demikian, isi dari preposisi aja dumeh tersebut memiliki unsur kebenaran yang dapat dibuktikan (Rahyono, 2009, p. 83)Meski ojo dumeh berasal dari budaya Jawa, kalau disosialisasikan secara benar dan terus menerus dan dengan memberikan arti yang tepat maka akan bisa diterima di semua lapisan masyarakat (Besar, 2010, p. 662). Dengan demikian dapat diartikan bahwa aja dumeh memiliki kandungan nilai-nilai moral kewarganegaraan, yang dapat di gunakan secara universal. Nilai-nilai moral kewarganegaraan tersebut seperti jujur dan adil, amanah/dapat dipercaya, bertata krama, dapat dipercaya. Jika dalam kehidupan berbangsa dan bernegara baik pemerintah maupun masyarakat mau secara konsisten menerapkan nilai-nilai tersebut maka niscaya Indonesia akan menjadi negara yang makmur dan maju. Misalnya saja bagaimana mungkin tindakan Korupsi terjadi apabila semua orang memiliki nilai jujur dan amanah akan apa yang menjadi tanggung jawabnya. Dengan memegang nilai adil maka seorang pemimpin akan menghindari adanya tindakan radikal, yang mana tindakan radikalisme seperti terorisme acap kali dipicu oleh keputusan yang tidak adil dari pemimpin/pemangku kebijakan (Mulyoto \& Mulyono, 2017, p. 69).

Mendhern jero artinya menutupi lubang sedalam-dalamnya dengan tanah yang telah digali, mikul dhuwur artinya mikul = memikul; dhuwur = atas. Jadi arti harfiah yaitu menutup, lubang sampai sedalam-dalamnya dan memikul sampai atas. Maksud ungkapan tersebut adalah kita sebagai anak atau generasi penerus harus melupakan atau melenyapkan keburukan, kejelekan atau kesalahan orang tua apalagi orang tua kita yang sudah meninggal dunia. Bagi orang Jawa, tidak baik mengungkit-ungkit atau mengungkapkan keburukan orang tua dan saudara yang sudah meninggal. Yang perlu dikenang adalah jasa mereka. Orang tua kita merupakan sarana Tuhan agar kita ada di dunia ini. Sedangkan makna dari mikul dhuwur atau memikul sampai di atas adalah sebagai generasi muda perlu menjunjung nama baik orang tua dengan menghindarkan diri dari perbuatan tercela. Apalagi bila para generasi muda memiliki prestasi sehingga membawa nama naik orang tua (Budiyono \& Feriandi, 2017). Senada dengan hal tersebut (Budiarto, 2016, p. 29) mendefinisikan bahwa mendhem jero mikul duwur dengan uphold all that is good and bury things that are not good, it should be opened to uphold kinship that was passed down from generation to generation.

Mendhem jero pada ungkapan tersebut tidak dapat kita artikan bahwa kita harus berdiam diri meski melihat kesalahan dari pimpinan ataupun saudara, kita tetap memiliki kewajiban untuk mengingatkannya dengan tata cara yang benar dan dengan pertimbangan yang matang. Mendem jero dalam hal ini dapat kita pahami apabila suatu kasus atau peristiwa telah selesai dan telah diadili maka kita sebagai warganegara tidak perlu mengungkitnya lagi, apalagi dijadikan sentimen-sentimen politik demi menjatuhkan lawan politiknya. Justru yang perlu untuk kita ungkit atau di junjung adalah keberhasilan atau kebaikan dari seseorang, sehingga dapat menjadi pelajaran dan motivasi bagi kita.

Dalam mengartikan ungkapan jer basuki mawa beya acap kali di pahami bila kita ingin berhasil perlu dan harus mengeluarkan biaya, agar kita berhasil dalam segala usaha (Bratawijaya, 1997). Namun yang harus kita ketahui adalah "beya" yang dimaksudkan pada ungkapan ini tentu saja tidak hanya sekadar mengharapkan biaya atas apa yang hendak akan dilakukan, dan hanya melakukan 
sesuatu apabila memperoleh dana ataupun bantuan dari pemerintah. Beya tersebut juga bisa diartikan sebagai sebuah pengorbanan yang harus ditebus guna mewujudkan citacita (Achmad, 2012, p. 74).

Dengan demikian nilai moral kewarganegaraan yang diperoleh dari istilah ini adalah, kemandirian, pantang menyerah, kerja keras. Nilai-nilai tersebut sangat penting dan berguna pada negara dengan konsep welfare state, menurut $\mathrm{TH}$ Marshal, negara dengan konsep welfare state mempunyai suatu kewajiban untuk meningkatkan dan menjamin kesejahteraan seluruh warganegaranya. Indonesia sendiri juga merupakan salah satu negara yang menggunakan bentuk welfare state, hal itu tercermin dari pembukaan UUD NRI Tahun 1945 yang berbunyi "Kemudian daripada itu untuk membentuk suatu Pemerintah Negara Indonesia yang melindungi segenap bangsa Indonesia dan seluruh tumpah darah Indonesia dan untuk memajukan kesejahteraan umum, mencerdaskan kehidupan bangsa, dan ikut melaksanakan ketertiban dunia yang berdasarkan kemerdekaan, perdamaian abadi dan keadilan sosial".

Dari hal itu maka secara sederhana, dapat dipahami bahwa Indonesia harus memiliki peran yang besar untuk menciptakan kesejahteraan bagi warganegaranya. Dalam konsepsi ini juga mengizinkan negara untuk terlibat dalam setiap bagian dari kehidupan masyarakat dan kebutuhan sehari-hari dalam rangka mencapai kemakmuran. Konkretnya negara bertanggung jawab untuk memberikan pelayanan dan kebutuhan dasar bagi warganya sampai pada tingkatan tertentu (Zain, Yurista, \& Yuniza, 2014, p. 64). Dengan menerapkan ungkapan jer basuki mawa beya meski Indonesia merupakan negara kesejahteraan (welfare state), warganegara tidak hanya menunggu bantuan negara untuk membuat mereka sejahtera melainkan juga berusaha keras sepenuh hati dengan mengorbankan waktu dan tenaga yang dimiliki.

Dalam suatu negara yang mencitacitakan civil society/masyarakat madani negara harus mempunyai komitmen untuk memperlakukan semua warganegaranya dengan setara tanpa melihat perbedaan suku, agama, ras, etnis. Untuk menyatukan berbagai macam perbedaan itu diperlukan lah suatu konsep yang berisi seperangkat ide-ide yang dapat diwujudkan secara efektif dalam representasi kebudayaan untuk tujuan pembentukan identitas warganegara atau dapat disebut civic culture (budaya kewarganegaraan). Sedangkan politic culture merupakan pemikiran yang khas tentang bagaimana kehidupan politik dan ekonomi yang seharusnya diselenggarakan (Winataputra, 2012, p. 57). Sehingga dari hal itu dapat kita pahami bahwa terdapat hubungan timbal balik antara civic culture dengan politic culture, dimana karakter atau identitas keindonesiaan yang ada dalam civic culture akan di bawa oleh para pelaku politik (eksekutif, legislatif) untuk dicerminkan dalam berbagai perilakunya sebagai wakil rakyat dalam konteks pembangunan sosial, politik, ekonomi dan budaya.

Dalam hubungannya dengan budaya Jawa, maka artikel ini bukan bermaksud untuk menonjolkan budaya dari suatu etnis tertentu, ataupun memaksakan suatu identitas/nilai-nilai kesukuan kepada suku lain. Pengalian budaya jawa pada artikel ini hanya bertujuan untuk membuktikan bahwa dalam budaya jawa terdapat nilai-nilai universal yang juga diterima secara menyeluruh oleh rakyat Indonesia, serta 
menjadi contoh cerminan penerapannya dalam budaya politik di Indonesia.

Sebagai bukti adanya hubungan budaya Jawa dengan pembentukan budaya kewargaan diketahui bahwa budaya jawa dipandang sangat mewarnai sikap, perilaku, dan orientasi politik kalangan elite politik di Indonesia (Gaffar, 2006; Jackson \& Pye, 1978; Rusadi, 2006; Winarno, 2007). Jackson (Jackson \& Pye, 1978, p. 23) menyatakan bahwa hubungan yang ada pada masyarakat Jawa disusun atas relasi hubungan yang bersifat tidak setara seperti pemimpin dengan pengikutnya (raja dan para abdinya/rakyatnya) yang memiliki sikap saling menghargai. Hal ini diperkuat dengan pendapat Gaffar (2006, p. 23) yang memandang masyarakat Jawa sebagai struktur yang bersifat hierarkis yang didasarkan pada aspek kekuasaan (politis), yang memiliki perbedaan tegas antara mereka yang memegang kekuasaan (priyayi sebagai pihak penguasa atau wong gedhe) dan rakyat kebanyakan (wong cilik).

Dari nilai budaya Jawa yang bersifat hierarkis tersebut pada akhirnya menjadi suatu civic virtue (budaya kewargaan) yang diterima oleh masyarakat Indonesia untuk diterapkan dalam kancah kehidupan berbangsa bernegara. Pada kehidupan sosial para birokrat misalnya, yang seringkali menampakkan diri dengan self-image atau citra diri yang bersifat benevolence, sehingga mewajibkan rakyat loyal kepada mereka. Rakyat diposisikan sebagai objek yang harus selalu menerima segala keputusan pemerintah dalam setiap kebijakan publik (Mulyawan, 2006, p. 15). Dampak yang kurang baik tersebut terjadi karena yang digali merupakan nilai-nilai yang juga memiliki dampak negatif, berbeda hanya dengan nilai-nilai moral kewarganegaraan yang ada dalam artikulasi budaya jawa seperti aja dumeh, mendhem jero mikul dhuwur, jer basuki mawa bea.

\section{Simpulan}

Beberapa ungkapan seperti aja dumeh, mendhem jero mikul dhuwur, jer basuki mawa bea memiliki nilai-nilai moral kewarganegaraan yang bersifat universal sehingga dapat menjadi karakter atau identitas keindonesiaan yang merupakan bagian dari civic culture. Sehingga dari hal itu dapat kita pahami bahwasanya budaya Jawa juga menjadi salah satu sumber pembentukan civic culture Indonesia. Nilai-nilai yang terkandung dalam civic culture kemudian akan di bawa oleh para pelaku politik (eksekutif, legislatif) untuk dicerminkan dalam berbagai perilakunya sebagai wakil rakyat dalam konteks pembangunan sosial, politik, ekonomi dan budaya (politic culture). Sehingga antara budaya jawa, civic culture dan politic culture memiliki suatu keterikatan yang berkesinambungan antara satu dengan yang lainnya.

\section{Daftar Pustaka}

Abdurrahman, H., \& Soerjono. (1999). Metode penelitian deskriptif. Jakarta: Rineka Cipta.

Achmad, S. W. (2012). Wisdom van Java: mendedah nilai-nilai kearifan Jawa. Yogyakarta: IN AzNa Books.

Bertens, K. (2005). Etika (9th ed.). Jakarta: PT. Gramedia Pustaka Utama.

Besar. (2010). Implementasi nilai-nilai falsafah Ojo Dumeh di kalangan mahasiswa Universitas Bina Nusantara. Humaniora, 1(45), 658-667.

Bratawijaya, T. W. (1997). Mengungkap dan mengenal budaya Jawa. Jakarta: Pradnya Paramita.

Budiarto, A. S. (2016). Concept of selfconservation in a traditional village: an empirical study of Kampong Kauman Semarang Indonesia. Nternational Transaction Journal of Engineering, Management, \& Applied Sciences \& 
Technologies. International Transaction Penelitian Hukum, 1(2), 63-76.

Journal of Engineering, Management, \& Applied Sciences \& Technologies, 7(1), 21-34.

Budiyono, B., \& Feriandi, Y. A. (2017). Menggali nilai-nilai kearifan lokal budaya Jawa sebagai sumber pendidikan karakter. In Prosiding Seminar Nasional Bimbingan dan Konseling (Vol. 1, pp. 92-103).

Gaffar, A. (2006). Politik Indonesia: transisi menuju demokrasi. Yogyakarta: Pustaka Pelajar.

Jackson, K. D., \& Pye, L. W. (Eds.). (1978). Political power and communications in Indonesia. London: Univ of California Press.

Muchson AR. (2009). Dimensi moral dalam Pendidikan Kewarganegaraan. Jurnal Civics: Media Kajian Kewarganegaraan, 6(16-28).

Mulyawan, B. (2006). Budaya politik masyarakat Indonesia dalam perspektif pembangunan politik. Jurnal Aspirasi, 5(2), 13-20.

Mulyoto, G. P., \& Mulyono, G. P. (2017). Radikalisme agama di Indonesia (ditinjau dari sudut pandang sosiologi kewarganegaraan). Citizenship, 5(1), 64-74.

Rahyono, F. X. (2009). Kearifan budaya dalam kata. Jakarta: Wedatama Widya Sastra.

Rusadi, K. (2006). Sistem politik Indonesia: suatu model pengantar. Bandung: Sinar Baru Aglesindo.

Winarno, B. (2007). Sistem politik Indonesia era reformasi. Jakarta: Gramedia Pustaka Utama.

Winataputra, U. S. (2012). Pendidikan kewarganegaraan dalam perspektif pendidikan untuk mencerdaskan kehidupan bangsa: gagasan, instrumentasi, dan praksis. Bandung: Widya Aksara Press.

Zain, M. A., Yurista, A. P., \& Yuniza, M. E. (2014). Konsistensi pengaturan jaminan sosial terhadap konsep negara kesejahteraan Indonesia. Jurnal 